\title{
EFFECT OF DIFFERENT EXTENDERS AND STORAGE PERIODS ON MOTILITY AND FERTILITY OF RAM SPERM
}

\author{
Rossen Georgiev Stefanov ${ }^{1}$, Georgi Anev², Desislava Vasileva Abadjieva ${ }^{1}$ \\ ${ }^{1}$ Institute of Biology and Immunology of Reproduction-BAS, \\ bul. Tsarigradsko Shose 73, p.c. 1113, Sofia, Bulgaria \\ ${ }^{2}$ Agricultural Institute, BG-Turgovishte, Bulgaria
}

Received 5 July 2014; Received in revised form 23 November 2014; Accepted 1 December 2014

\begin{abstract}
The aim of this study was to test the effect of extenders containing different sugar in their composition on ram sperm motility and pregnancy rate of ewe's following artificial insemination. Semen were collected from ten North-east Bulgarian fine-fleece breed and tested for quality. Semen was diluted with different extenders, with di- and trisaccharides. A series of experiments were repeated in triplicate. Total motility was determined by using Sperm Analysis (SCA, Microptic, Spain). A total of 200 North-east Bulgarian fine-fleece breed mature ewes were used for cervical insemination with a sperm dose at the concentration of 100 × $10^{6}$ spermatozoa. Pregnancies were diagnosed 60 days after AI by - a real-time ultrasonic scan device (Alloka SSD 500). In conclusion, our experiments demonstrated that higher sperm motility after storage at $4^{\circ} \mathrm{C}$ for 24 hours and 48 hours has a ram spermatozoa diluted with extender 1, with combination of disaccharides (sucrose and lactose) and trisaccharides (rafinosa). This semen extender (number 1) can be used for successful insemination of ewes and to enhance pregnancy rate after artificial insemination.
\end{abstract}

Key words: ram, sperm extenders, motility, fertility

\section{INTRODUCTION}

Artificial insemination with chilled-stored semen has become a technique in sheep breeding (1). Efforts have been made to improve the preservation of ram semen by the modification of extender composition (2), as well as with the addition of various components to maintain motility, fertilizing capacity and preserve sperm membrane integrity $(3,4,18)$. The preservation of functional properties of sperm in the storage medium is dependent on the quantities of non-electrolytes. The spermatozoa require exogenous substrates to obtain energy through mitochondrial oxidative phosphorylation and glycolysis by the consumption of glycolysable sugars, such as glucose, fructose, mannose (5).

Corresponding author: Assoc. Prof. Rossen Stefanov, $\mathrm{PhD}$ E-mail address: stefanovrossen@gmail.com

Present address: Institute of Biology and Immunology of ReproductionBAS, bul. Tsarigradsko shose 73, p.c. 1113, Sofia, Bulgaria

Copyright: (C) 2015 Stefanov R. This is an open-access article published under the terms of the Creative Commons Attribution License which permits unrestricted use, distribution, and reproduction in any medium, provided the original author and source are credited.

Competing Interests: The authors have declared that no competing

interests exist.

Available Online First: 5 December 2014

http://dx.doi.org/10.14432/j.macvetrev.2014.12.036
Fructose is thought to be a major energy source for ejaculated spermatozoa, and together with glucose is found in the seminal plasma in many mammalian species. In many species, glucose and fructose have been investigated for their different effects on gametes in terms of metabolizable energy and fertility potential, but the beneficial effects vary between species (6). The effects of sugars on the metabolism of freshly ejaculated spermatozoa has been studied in rams, but metabolize glucose and fructose use different pathways, resulting in separate systems of energy management as indicated by their different roles in glycogen metabolism and motility patterns (7). Sugars are the most commonly used components for semen extenders; however, the concentration of these sugars in the extenders varies markedly.

To optimize the extender medium for the achievement of best storage semen characteristics which would infer greater fertility, it is important to study the influence of different sugars on rams spermatozoa. The aim of this study was to test the effect of three extenders with different ratios of sugar in their composition on ram sperm motility and pregnancy rate of ewe's following insemination. 


\section{MATERIAL AND METHODS}

\section{Animals}

The experiment was carried out on June and July in the Experimental station of agriculture (Targovishte, Bulgaria). Ten clinically healthy rams from north-east Bulgarian fine-fleece breed, around three years old and 70-98 kg of live weight were used as a semen source. Semen was collected using an artificial vagina two times a week. Fresh semen with $\geq 70 \%$ motility was eligible for experimentation.

\section{Extenders}

The extenders were used to dilute the samples of semen to be chilled. Semen was diluted with two different extenders (Table 1), which gave the best result after prior experiment with twelve extenders with mono-, di- or three disacharide. The third extender served as a control (8). All series of experiments (I-III) were repeated in triplicate.

Prior to sugar measurement, each egg-yolk was mixed in distilled water to the same final concentration as in the extenders, i.e., $20 \%(\mathrm{v}: \mathrm{v})$. To make the extenders, fresh egg-yolks were pooled and mixed to reduce the biological variation found in the eggs. and concentrations by using sperm analyzer SCA (Microptic, Barcelona, Spain). For each sample, at least 200 sperm cells from four randomly selected fields were evaluated.

\section{Pregnancy rate experiment}

A total of 200 North-east Bulgarian fine-fleece breed mature ewes (2-3 years old) were used for insemination. The detection of ewes in clinically manifested oestrus was performed in the morning by ram tester. The ewes were cervically inseminated with a sperm dose at the concentration of $100 \times 10^{6}$ spermatozoa. The insemination was reiterated second time after $10 \mathrm{~h}$ with the same sperm, which was stored $48 \mathrm{~h}$.

Pregnancy was diagnosed 60 days after AI by ultrasonic scan device (Alloka SSD 500).

\section{Statistical analyses}

The statistical analyses were performed by GraphPad software, using the pairwise t-tests for comparison of the least-squares means. The pregnancy rate (number of pregnant ewes to number of inseminated) in all groups was statistically analyzed using a chi-square test. A value of $\mathrm{p}<0,05$ was considered statistically significant.

Table 1. Compositions of semen extenders used in the experiments

\begin{tabular}{lccc}
\hline Ingredients & I & II & III \\
\hline Na-citrate (g) & 2.8 & 2.8 & 2.8 \\
Saccharosa (g) & 0.267 & 0.4 & 0.4 \\
Lactose (g) & 0.267 & - & 0.4 \\
Rafinosa (g) & 0.267 & 0.4 & - \\
Egg-yolk (mL) & 0.25 & 0.25 & 0.25 \\
Distilled water (mL) & to 100 & to 100 & to 100 \\
\hline
\end{tabular}

\section{Experimental design}

The pooled semen was divided into three equal aliquots and placed in three screw cap closed sterile plastic tubes. The resulting sperm samples were divided and re-suspended in ratio 1:4 with different extenders to reach a final sperm concentration of $2 \times 10^{6}$ cells $/ \mathrm{mL}$. To avoid cooling too rapidly, the extended semen samples were placed in a room temperature cooler, which reached a temperature of $4^{\circ} \mathrm{C}$ within $45 \mathrm{~min}$. Subsequently, all samples were stored at $4^{\circ} \mathrm{C}$ in a refrigerator for 24 and 48 hours and after that semen samples were evaluated daily during the first three days, as motility was determined on $15 \mathrm{~min}$; $60 \mathrm{~min} ; 120 \mathrm{~min} ; 180 \mathrm{~min} ; 240 \mathrm{~min} ; 300 \mathrm{~min}$ and $360 \mathrm{~min}$, after incubation in the water bath at $39^{\circ} \mathrm{C}$. The semen samples were evaluated microscopically which included percentage of motile spermatozoa

\section{RESULTS}

Three different extenders were used for the motility of the spermatozoa at different postdilution intervals.

Total motility $(\%)$ decreased with storage time in all cases (Table 2). However, the type of extender significantly $(\mathrm{P}<0.05 ; \mathrm{P}<0.001)$ affected the percent sperm motility. Combination of sucrose, lactose and rafinosa in extender 1 showed highest values than other extenders $(\mathrm{P}<0.001)$ regarding this characteristic after $240 \mathrm{~min}$ to $360 \mathrm{~min}$.

Data indicate that the survival of sperm cells on fresh ram semen in extender 1 and 3 had similar values after 6 hours incubated at $39^{\circ} \mathrm{C}(\mathrm{P}<0.001)$. Extender 2 showed significantly lower protective qualities $(\mathrm{P}<0.001)$. After 48 hours, only semen diluted with extender 1 showed living and motile 
Effect of different extenders and storage periods on ram sperm

Table 2. Effect of extender with different sugar contents on the sperm motility in rams on $24 \mathrm{~h}$ and $48 \mathrm{~h}$ at $39^{\circ} \mathrm{C}$

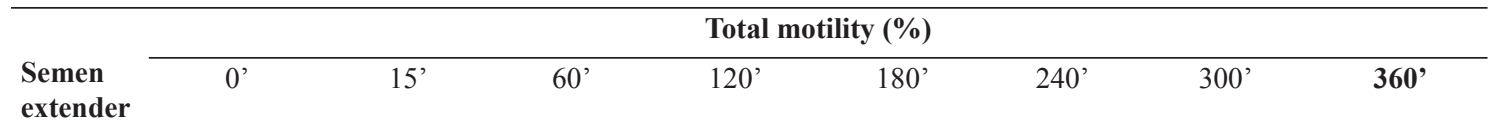

\begin{tabular}{|c|c|c|c|c|c|c|c|c|}
\hline \multirow[b]{2}{*}{$1 \mathrm{M}$} & \multicolumn{8}{|c|}{ After $24 \mathrm{~h}$} \\
\hline & $77.0 \pm 0.90$ & $70.8 \pm 1.3$ & $63.33 \pm 0.38$ & $53.67 \pm 0.62$ & $34.67 \pm 0.81$ & $33.60 \pm 0.43$ & $25.67 \pm 0.33$ & $19.83 \pm 0.16$ \\
\hline $\mathrm{S}^{*}$ & n.s. & n.s. & $\mathrm{a}$ & $\mathrm{D}, \mathrm{E}$ & $\mathrm{b}, \mathrm{F}$ & $A_{1}, B_{1}$ & $\mathrm{D}_{1}, \mathrm{c}$ & $F_{1}, A_{2}$ \\
\hline $2 \mathrm{M}$ & $77.8 \pm 0.66$ & $72.2 \pm 1.7$ & $64.00 \pm 0.17$ & $50.00 \pm 0.32$ & $9.00 \pm 1.40$ & $25.00 \pm 0.73$ & $15.00 \pm 0.31$ & $8.00 \pm 0.60$ \\
\hline$S^{*}$ & n.s & n.s. & $\mathrm{C}$ & $\mathrm{D}$ & $\mathrm{b}$ & $\mathrm{A}_{1}, \mathrm{C}_{1}$ & $\mathrm{D}_{1}, \mathrm{E}_{1}$ & $\mathrm{~F}_{1}, \mathrm{~B}_{2}$ \\
\hline $3 \mathbf{M}$ & $78.0 \pm 0.52$ & $71.0 \pm 2.6$ & $62.17 \pm 0.28$ & $49.50 \pm 0.40$ & $39.83 \pm 0.45$ & $30.93 \pm 0.20$ & $24.67 \pm 0.27$ & $17.43 \pm 0.19$ \\
\hline \multirow[t]{2}{*}{$\mathrm{S}^{*}$} & n.s. & n.s. & $\mathrm{a}, \mathrm{C}$ & $\mathrm{E}$ & $\mathrm{F}$ & $\mathrm{B}_{1}, \mathrm{C}_{1}$ & $\mathrm{c}, \mathrm{E}_{1}$ & $A_{2}, B_{2}$ \\
\hline & \multicolumn{8}{|c|}{ After 48 h } \\
\hline $1 \mathrm{M}$ & $70.0 \pm 0.11$ & $65.33 \pm 1.36$ & $62.4 \pm 1.54$ & $41.6 \pm 1.65$ & $32.1 \pm 0.98$ & $22.3 \pm 1.32$ & $18.0 \pm 1.07$ & $10.1 \pm 0.39$ \\
\hline$S^{*}$ & n.s & A & a & n.s. & d & $\mathrm{A}, \mathrm{e}$ & B & \\
\hline $2 \mathrm{M}$ & $70.0 \pm 0.24$ & $68.50 \pm 1.28$ & $57.1 \pm 1.30$ & $41.8 \pm 1.30$ & $28.3 \pm 1.50$ & $13.2 \pm 0.96$ & 0 & $\mathbf{0}$ \\
\hline$S^{*}$ & n.s. & $\mathrm{A}, \mathrm{B}$ & $\mathrm{a}$ & n.s. & n.s. & A & & \\
\hline $3 \mathbf{M}$ & $70.0 \pm 0.45$ & $65.83 \pm 1.52$ & $58.6 \pm 1.71$ & $43.2 \pm 1.19$ & $26.3 \pm 1.65$ & $15.6 \pm 1.85$ & $9.3 \pm 1.00$ & $\mathbf{0}$ \\
\hline$S^{*}$ & n.s. & B & n.s. & n.s. & $\mathrm{d}$ & $\mathrm{e}$ & B & \\
\hline
\end{tabular}

S*-values with same superscripts are significant $\mathrm{a}, \mathrm{b}, \mathrm{c}-\mathrm{P} \leq 0.05 ; \mathrm{d}, \mathrm{e}-\mathrm{P} \leq 0.01 ; \mathrm{A}_{\mathrm{n}-2}, \mathrm{~B}_{\mathrm{n}-2}, \mathrm{C}, \mathrm{D}, \mathrm{E}, \mathrm{F}-\mathrm{P} \leq 0.001$

sperm cells (total motility $=10.1 \%$ ). Samples, which were diluted with extenders 2 or 3 showed no protective effect on ram semen, since all spermatozoa were dead.

The beneficial effect of more sugar concentrations in maintaining higher TM\% was consistent.

Values for pregnancy rates are presented in Table 3. There were significant differences between the extender 1 - sucrose, lactose and rafinosa (80\%) and extender 2 - sucrose and rafinosa (71\%), also between extender 1 and control extender 6A- with sucrose and lactose (71.20\%; Table 3). different metabolism (7). Sperm motility gives a measure of the integrity of the sperm axoneme and tail structures as well as the metabolic machinery of the mitochondria, and sperm morphology is a surrogate measure of the integrity of DNA packaging and the quality of spermatogenesis (9). The results from the present study clearly demonstrated the major effect of sucrose, lactose and rafinosa in semen extenders on chilled ram sperm motility. Total motility is an important indicator of sugar utilization by spermatozoa as the sugars provide the external energy source essential

Table 3. Ewe's pregnancy rate after cervical insemination with ram sperm diluted in extenders

\begin{tabular}{cccc}
\hline $\begin{array}{c}\text { Semen } \\
\text { extender }\end{array}$ & No of inseminated ewes (n) & $\begin{array}{c}\text { No of pregnant ewes } \\
\text { (n) }\end{array}$ & $\begin{array}{c}\text { Pregnancy rate } \\
(\%)\end{array}$ \\
\hline $\mathbf{1}$ & 65 & 52 & $80.00 \% \mathrm{a}, \mathrm{b}$ \\
$\mathbf{2}$ & 69 & 49 & $71.01 \% \mathrm{a}$ \\
$\mathbf{3}$ & 66 & 47 & $71.21 \% \mathrm{~b}$ \\
\hline
\end{tabular}

Values with same superscripts are significant $a, b-p \leq 0.05$

\section{DISCUSSION}

Different sugars were tested and compared to the untreated control because they have been shown to have protective effects on motility patterns and for maintaining motility. In this study, TM\% $(>70 \%)$ remained high during the first 48 hours and subsequently, as could be expected, decreased with storage time. The decrease in the percentage of total motile spermatozoa in $0^{6}-15^{\circ}(71-78 \%)$ may 
be due to the fact that there are subpopulations of ram spermatozoa with different sensitivities to changes in the environment, particularly reduced temperature. Decreased sperm motility after $60^{\prime}$ has been postulated to be due to temperature sensitivity of the ATPase-linked sodium-potassium pump and subsequently a leakage of ions (10). Preservation with increasing variety of sugars resulted in better maintenance of sperm motility with extender 1 . The combination of sucrose, lactose and rafinosa as a part of semen extender for ram semen provided beneficial effect on the survival of sperm more than as sole component. Bohlooli et al. establish that only sucrose and lactose in extenders was less effective at protecting spermatozoa during the storage process, which was indicated clearly by lower osmotic resistance of spermatozoa (11). In addition, the increased concentration of buffer solutions in the extender reduces the deleterious effects of the great amount of hydrogenic ions produced from the metabolic activity of spermatozoa. In addition, egg yolk is known to contain many specific components like lecithin, phospholipids and lipoprotein fractions (12). The significantly higher sperm motility after storage for 24 hours and 48 hours could explain the evolution of fertilizing ability and was probably

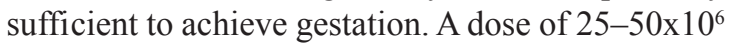
sperm for intrauterine insemination, $75-100 \times 10^{6}$ sperm for transcervical insemination and $150-300 \times 10^{6}$ for cervical insemination is recommended in ewes (13). In the present study, concentration of $100 \times 10^{6}$ ram spermatozoa was selected for in vivo use. The change in the motility parameter was less dramatic in samples diluted with extender 1 and significant difference was observed between the groups regarding the fertilization rate or the establishment of pregnancy. It was reported that low motile sperm injection may have a negative effect on fertilization and pregnancy rates (14). On the other hand Vildan Karpuz et al. found no correlation in fertilization and pregnancy rates with either morphology or motility (15).

The possible physiological reasons for the decline in motility might be due to extracellular oxidative stress, effects of seminal plasma volume-constituents and endogenous free radical production. Substances from seminal plasma protect spermatozoa from premature aging during storage (16). The most sugars in content of extender 1. may be one of the reasons for better preservation of functional and motility parameters in our study.

In conclusion, our experiments demonstrated that higher sperm motility after storage at $4^{\circ} \mathrm{C}$ for 24 hours and 48 hours has the ram spermatozoa diluted with extender 1 . with combination of disaccharides 88 (sucrose and lactose) and trisaccharides (rafinosa). This semen extender (number 1) can be used successfully for the insemination of ewes and it might improve the pregnancy rate after artificial insemination.

\section{REFERENCES}

1. Ax, R. L., Dally, M. R., Didon, B. A, Lenz, R. W., Love, C. C., Varner, D.D., Hafez, B., Bellin, M. E. (2000). Artificial insemination. In: Hafez, B.Hafez, E.S.E. (Eds.), Reproduction in farm animals. ( $7^{\text {th }}$ Eds.) (pp. 376-389). Philadelphia, Lea and Febinger ISBN 0-683-30577-8

2. Marti, J. I., Marti, E., Cebrian-Perez, J. E., Muino-Blanco, T. (2003). Survival rate of antioxidant enzyme activity of ram spermatozoa after dilution with different extenders or selection by a dextran swim-up procedure. Theriogenology 60, 1013-1020. http://dx.doi.org/10.1016/S0093-691X(03)00105-5

3. Riha, L., Apolen, D., Pivko, J., Grafenau, P., Kubovica, E. (2006). Influence of implememtors on sheep fertility out of season. Slovak J. Anim. Sci., 4, 180-182.

http:/www.cvzv.sk/index.php/en/volume-39-2006/ number-4

4. Sarlos, P., Molnar, A., Kokai, A., Gabor, G., Ratky, J. (2002). Evaluation of the effect of antioxidants in the conservation of ram semen. Acta Vet. Hung., 50, 2, 235-245.

http://dx.doi.org/10.1556/AVet.50.2002.2.13 PMid:12113179

5. Adeoya-Osiguwa S., Fraser, L. R. (1993). A biphasic pattern of $45 \mathrm{Ca}^{2+}$ uptake by mouse spermatozoa in vitro correlates changing functional potential. J. Reprod. Fertil., 99, 187-194.

http://dx.doi.org/10.1530/jrf.0.0990187 PMid:8283437

6. Williams, AC, Ford, WCL., (2001). The role of glucose in supporting motility and capacitation in human spermatozoa. J. Androl., 22, 680-695. PMid: 11451366

7. Rigau, T., Farrem, M., Ballester, J., Mogas, T., Peňa, A., Rodriguez-Gil, J.E. (2001). Effects of glucose and fructose on motility patterns of dog spermatozoa from fresh ejaculates. Theriogenology 56, 801-815. http://dx.doi.org/10.1016/S0093-691X(01)00609-4

8. Zahariev Z., Georgiev, G., Chelebiyski, S. (1988). Diluent for storage of ram semen for 24 hours at $3-4{ }^{\circ} \mathrm{C}$. Journal of Livestock Breeding (BG), 6, 65-66.

9. Pacey, A.A. (2006). Is quality assurance in semen analysis still really necessary? A view from the andrology laboratory. Hum Reprod., 21, 1105-1109. http://dx.doi.org/10.1093/humrep/dei460 PMid:16396933 
Effect of different extenders and storage periods on ram sperm

10. Saito, K., Kinoshita, Y., Kanno, H., Iwasaki, A. (1996). The role of potassium ion and extracellular alkalization in reinitiation of human spermatozoa preserbed in electrolyte-free solution at $4^{\circ} \mathrm{C}$. Fertil Steril., 56, 1214-1218.

11. Bohlooli, Sh., Cedden, F., Jang, J. P., Razzaghzadeh, S., Bozoğlu, Ş. (2012). The effect of different extenders on post-thaw sperm viability, motility and membrane integrity in cryopreserved semen of Zandi Ram. J. Basic. Appl. Sci. Res., 2 (2): 1120-1123.

12. Demianowicz, W., Strzezek, J. (1996). The effect of lipoprotein fraction from egg yolk on some of the biological properties of boar spermatozoa during storage of the semen in liquid state. Reprod. Dom. Anim., 31: 279-280.

http://dx.doi.org/10.1111/j.1439-0531.1995.tb00051.x

13. Buckrell, B. (1997). Reproductive technologies in commercial use for sheep, goats and framed deer. In: Proceedings for Annual Meeting of the Society for Theriogenology. (pp.185-192). Montreal, Quebec, Canada

14. Lui, J., Nagy, Z., Tournaye, H., et al. (1995). Analysis of 76 total fertilization failure cycles out of 2732 intracytoplasmic sperm injection cycles. Hum Reprod, 10: 2630-36.

http://humrep.oxfordjournals.org/content/10/10/2630
15. Karpuz, V., Gokturk, A., Koyuturk, M. (2007). The effects of sperm morphology and motility on the outcome of intracytoplasmic sperm injection. Marmara Medical Journal 20(2): 92-97.

http://www.marmaramedicaljournal.org/pdf. php3?id=418

16. Kasimanickam, R., Pelzer, K. D., Kasimanickam, V., Swecker, W.S., Thatcher, C.D. (2006). Association of classical semen parameters, sperm DNA fragmentation index, lipid peroxidation and antioxidant enzymatic activity of semen in ram-lambs. Theriogenology 65 , 1407-1421.

http://dx.doi.org/10.1016/j.theriogenology.2005.05.056

17. Varisli, O., Uguz, C., Agca C., Agca, Y. (2009). Motility and acrosomal integrity comparisons between electro-ejaculated and epididymal ram sperm after exposure to a range of anisosmotic solutions, cryoprotective agents and low temperatures. Animal Reproduction Science 110, 256-268.

http://dx.doi.org/10.1016/j.anireprosci.2008.01.012 PMid:18294786

18. Nikolovski, M., Mickov, Lj., Dovenska, M., Petkov, V., Atanasov, B., Dovenski, T. (2014). Influence of glutathione on kinetic parameters of frozen-thawed spermatozoa from Ovchepolian Pramenka rams. Mac Vet Rev, 37 (2): 121-128.

http://dx.doi.org/10.14432/j.macvetrev.2014.05.014 